\title{
Pyrolysis Gas Chromatography-Mass Spectrometry of Mycobacterial Mycolic Acid Methyl Esters and Its Application to the Identification of Mycobacterium leprae
}

\author{
By TAKASHI KUSAKA ${ }^{1 *}$ AND TATSUO MORI ${ }^{2}$ \\ 'Biochemistry Department, Kawasaki Medical School, Kurashiki, Japan \\ ${ }^{2}$ Research Institute for Microbial Diseases, Osaka University, Osaka, Japan
}

(Received 7 April 1986; revised 14 July 1986)

Pyrolysis gas chromatography-mass spectrometry of methyl mycolates from 32 species of mycobacteria, including Mycobacterium leprae, was carried out. The mycobacteria could be classified into four groups in respect of the fatty acid ester patterns detected within the range $C_{20}$ to $\mathrm{C}_{26}$. The applicability of this pyrolysis-gas chromatographic method for identifying $M$. leprae is discussed.

\section{INTRODUCTION}

The mycolic acids from Mycobacterium leprae have been analysed in some detail by highperformance liquid chromatography (HPLC), mass spectrometry (MS) and proton nuclear magnetic resonance spectrometry (NMR) (Asselineau et al., 1981; Kusaka et al., 1981; Draper et al., 1982; Minnikin et al., 1985). It was found that $M$. leprae has two homologous series of mycolates, whose main structural characteristic seemed to be in the alkyl branch at the $\alpha$-carbon having a relatively shorter chain length than for other mycobacterial mycolates. In order to determine whether the structure of the $\alpha$-branch is specific for $M$. leprae, pyrolysis gas chromatography-mass spectrometry (GC-MS) of mycolates isolated from 32 species of mycobacteria was carried out.

\section{METHODS}

Organisms. Foot-pads of nude mice ( $n u / n u$ ) killed one year after inoculation with $M$. leprae (Tai-53) were used as the source of $M$. leprae. All other species of cultivable mycobacteria, grown on $1 \%$ Ogawa's media, were supplied from the Laboratory for Culture Collection of the Institute for Microbial Diseases of Osaka University.

Isolation of mycolates. For isolating mycolates directly from the foot-pads of nude mice, the tissues were chopped into small pieces with scissors. Saponification of these tissues or cultivated mycobacterial cells was done by heating at $85^{\circ} \mathrm{C}$ for $4 \mathrm{~h}$ in more than 10 vols $5 \%(\mathrm{w} / \mathrm{v}) \mathrm{KOH}$ in $50 \%(\mathrm{v} / \mathrm{v})$ ethanol under reflux. The suspension was then acidified (below pH 2) with $6 \mathrm{M}-\mathrm{HCl}$ and extracted three times with $n$-hexane/diethyl ether $(1: 1, \mathrm{v} / \mathrm{v})$. The extract was evaporated to dryness and the residue containing total fatty acids was dissolved in a small volume of tetrahydrofuran and analysed by HPLC (Shimadzu-LC4), using a gel-permeation column (HSG-15, Shimadzu Co., $79 \mathrm{~mm}$ in diameter and $1 \mathrm{~m}$ in length) and a differential refractometer detector (Shimadzu RID-4). Various polystyrene standards of known $M_{\mathrm{r}}$ (Waters) were used to obtain a calibration curve. The flow rate of tetrahydrofuran was $2 \mathrm{ml} \mathrm{min}-1$. The eluate corresponding to material of $M_{\mathrm{r}}>1000$, assumed to contain total mycolates, was collected and evaporated to dryness.

Pyrolysis GC-MS and pyrolysis GC of methyl mycolates. The total mycolates, obtained as above, were dissolved in a small volume of diethyl ether then esterified with diazomethane. The methyl mycolates were analysed with a GC-MS instrument (Hitachi, M80-B), equipped with a Curie-point pyrolyser (Packard, model 891) fitted with a $3 \% \mathrm{OV}-1$ column ( $3 \mathrm{~mm}$ in diameter, $1 \mathrm{~m}$ in length), and using the electron-impact mode of MS. Methyl mycolates were also analysed by pyrolysis GC using a Shimadzu GC-8A instrument equipped with the same pyrolyser and column as above for quantitative analysis of the fatty acids. 

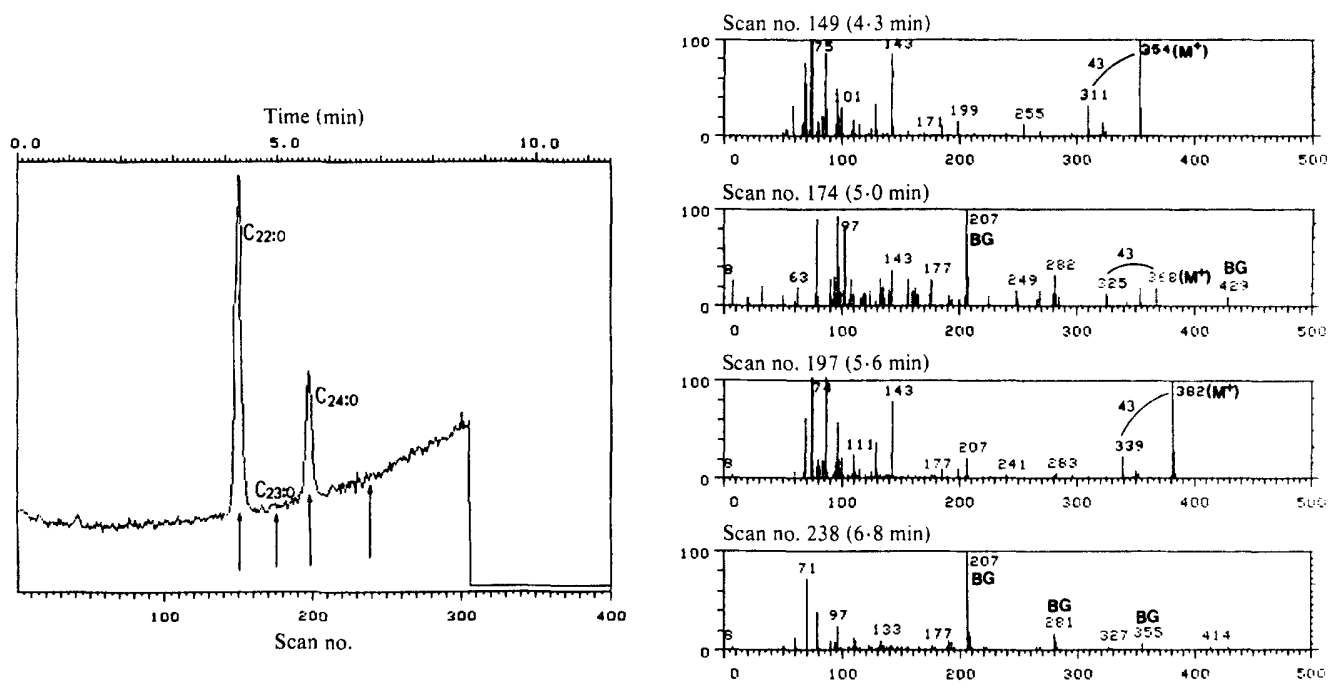

Fig. 1. Pyrolysis GC-MS of $M$. leprae mycolates. Pyrolysis was performed at $358^{\circ} \mathrm{C}$ for $10 \mathrm{~s}$ and the GC column (OV-1) temperature was programmed from $180^{\circ} \mathrm{C}$ to $300^{\circ} \mathrm{C}$ at the rate of $10^{\circ} \mathrm{C} \mathrm{min}^{-1}$. The mass spectra shown on the right were scanned at the times marked with arrows in the total ion chromatogram on the left. 'BG' in the mass spectra means background from the column.

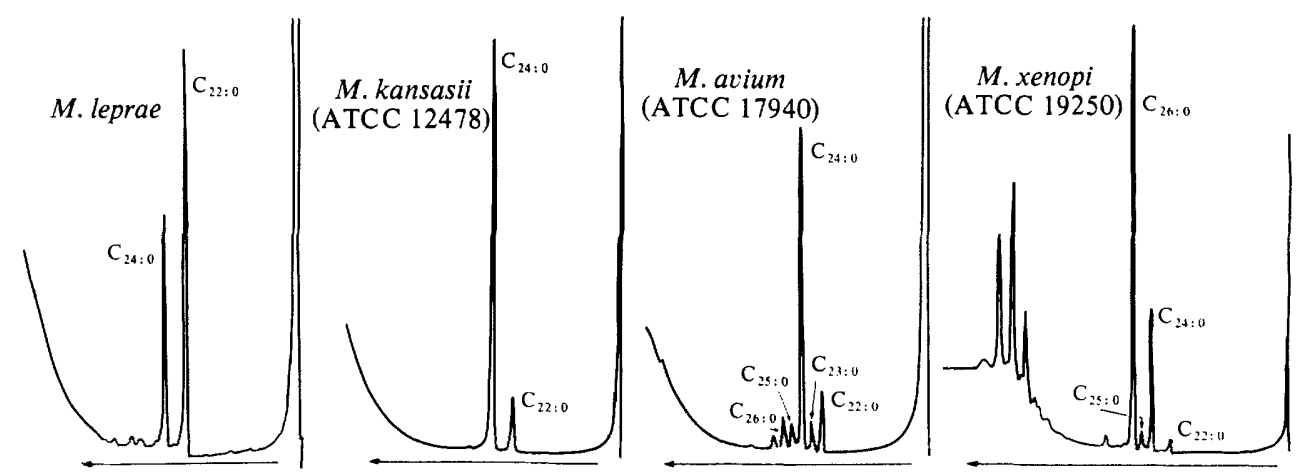

Fig. 2. Pyrolysis GC of mycolates from four mycobacterial species. The column (OV-1) temperature was programmed from $180^{\circ} \mathrm{C}$ to $300^{\circ} \mathrm{C}$ at the rate of $10^{\circ} \mathrm{C} \mathrm{min}-1$.

\section{RESULTS}

\section{Pyrolysis GC-MS and pyrolysis GC of methyl mycolates}

Pyrolysis of methyl mycolates at about $300^{\circ} \mathrm{C}$ yields long-chain meroaldehydes and fatty acid methyl esters having two carbon atoms more than the $\alpha$-branch of the original mycolates (Etémadi, 1967). Accordingly, pyrolysis GC-MS and pyrolysis GC of mycolates from 32 species of mycobacteria (including $M$. leprae) was done to investigate how the $\alpha$-branches of $M$. leprae mycolates compare with those of other mycobacteria. The results from the pyrolysis GC-MS of the $M$. leprae mycolates are shown in Fig. 1 and those from pyrolysis GC of mycolates from four species in Fig. 2. Summarized results for all species are shown in Table 1.

The $\alpha$-branches of all the mycobacterial mycolates were straight alkyl chains having from 18 to 24 carbons. The 32 species of mycobacteria could be classified into the following four groups in respect of the fatty acid pattern detected by pyrolysis GC-MS of the mycolates: a '22-group' having fatty acid from 20 to 24 carbons with $C_{22}$ predominating, a '24-group' having 22 to 24 
Table 1. Four groups of mycobacteria on the basis of pyrolysis GC-MS and pyrolysis GC of mycolates

The ratio of fatty acid methyl esters was calculated from the GC peak size, measured by multiplication of the height of the peak by its width at half height, and the mean value was obtained from three GC experiments.

\begin{tabular}{|c|c|}
\hline Sroup & Species* \\
\hline $2^{\prime}$ & $\begin{array}{l}\text { M. neoaurum (ATCC 25796) } \\
M . \text { parafortuitum (ATCC 19686) } \\
\text { M. diernhoferi (ATCC 19344) } \\
\text { M. leprae (Tai 53) } \\
\text { M. vaccae (ATCC 23014) } \\
\text { M. aurum (ATCC 25793) }\end{array}$ \\
\hline $24^{\prime}$ & $\begin{array}{l}M . \text { phlei (ATCC 23042) } \\
M . \text { rhodesiae (5298) } \dagger \\
\text { 'M. kanazawa' (ATCC 25810) } \\
M . \text { chitae (ATCC 19629) } \\
M . \text { smegmatis (ATCC 14468) } \\
\text { 'M. peregrinum' (ATCC 23022) } \\
M . \text { fortuitum (ATCC 19542) } \\
M . \text { chelonei (ATCC 19977) } \\
M . \text { flavescens (ATCC 23033) } \\
M . \text { thermoresistibile (ATCC 19529) } \\
M . \text { gastri (ATCC 15754) } \\
M . \text { nonchromogenicum (ATCC 19530) } \\
M . \text { gordonae (ATCC 23285) } \\
M . \text { kansasii (ATCC 12478) } \\
M . \text { triviale (ATCC 19368) } \\
M . \text { terrae (ATCC 15755) } \\
M . \text { scrofulaceum (ATCC 19073) } \\
M . \text { ulcerans (NCTC 10417) }\end{array}$ \\
\hline ", & $\begin{array}{l}\text { M. avium (ATCC } 17940) \\
\text { M. intracellulare (ATCC 19077) } \\
\text { M. marinum (1160) } \dagger \\
\text { M. lepraemurium (Hawaiian strain) }\end{array}$ \\
\hline 26 & $\begin{array}{l}\text { M. tuberculosis }\left(\mathrm{H}_{37} \mathrm{Ra}\right) \\
\text { M. simiae }(25) \dagger \\
\text { M. xenopi (ATCC 19250) } \\
\text { M. bovis BCG (Tokyo strain) }\end{array}$ \\
\hline
\end{tabular}

\begin{tabular}{|c|c|c|c|c|c|c|c|}
\hline \multicolumn{7}{|c|}{$\begin{array}{l}\text { Ratio of fatty acid methyl ester } \\
\qquad\left(C_{24: 0}=1.00\right)\end{array}$} & \multirow{2}{*}{$\begin{array}{l}\text { Time for } \\
\text { colony formation } \\
\text { on } 1 \% \text { Ogawa's } \\
\text { growth medium }\end{array}$} \\
\hline $\mathrm{C}_{20: 0}$ & $\mathrm{C}_{21: 0}$ & $\mathrm{C}_{22: 0}$ & $\mathrm{C}_{23: 0}$ & $\mathrm{C}_{24: 0}$ & $\mathrm{C}_{25: 0}$ & $\mathrm{C}_{26: 0}$ & \\
\hline 0.40 & $0 \cdot 15$ & $9 \cdot 60$ & 0.30 & 1.00 & & & $<3 d$ \\
\hline $0 \cdot 11$ & 0.06 & $7 \cdot 48$ & 0.01 & 1.00 & & & $<3 d$ \\
\hline \multirow[t]{2}{*}{0.13} & & $5 \cdot 25$ & 0.04 & 1.00 & & & $<3 d$ \\
\hline & & $2 \cdot 68$ & 0.02 & 1.00 & & & $\infty$ \\
\hline 0.02 & 0.01 & 1.68 & 0.04 & 1.00 & & & $<3 d$ \\
\hline \multirow[t]{27}{*}{0.04} & 0.01 & $1 \cdot 20$ & 0.02 & 1.00 & & & $<3 d$ \\
\hline & & 0.82 & 0.04 & 1.00 & & & $<3 d$ \\
\hline & & 0.68 & 0.07 & 1.00 & & & $<3 \mathrm{~d}$ \\
\hline & & 0.41 & 0.02 & 1.00 & & & $<3 d$ \\
\hline & & $0 \cdot 16$ & & $1 \cdot 00$ & & & $<3 \mathrm{~d}$ \\
\hline & & 0.15 & 0.01 & 1.00 & & & $<3 \mathrm{~d}$ \\
\hline & & 0.06 & 0.02 & $1 \cdot 00$ & & & $<3 d$ \\
\hline & & 0.04 & & 1.00 & & & $<3 d$ \\
\hline & & 0.03 & & 1.00 & & & $<3 d$ \\
\hline & & $0 \cdot 19$ & & 1.00 & & & $<7 d$ \\
\hline & & 0.06 & & 1.00 & & & $<7 d$ \\
\hline & & 0.29 & 0.03 & 1.00 & & & 2-3 weeks \\
\hline & & 0.28 & 0.06 & 1.00 & & & 2-3 weeks \\
\hline & & $0 \cdot 20$ & & 1.00 & & & $2-3$ weeks \\
\hline & & 0.13 & & 1.00 & & & $2-3$ weeks \\
\hline & & 0.13 & & 1.00 & & & 2-3 weeks \\
\hline & & 0.05 & & 1.00 & & & 2-3 weeks \\
\hline & & 0.04 & & 1.00 & & & 2-3 weeks \\
\hline & & & & 1.00 & & & 4-7 weeks \\
\hline & & $0 \cdot 18$ & 0.09 & 1.00 & 0.08 & $0 \cdot 10$ & $2-3$ weeks \\
\hline & & $0 \cdot 14$ & 0.06 & $1 \cdot 00$ & 0.06 & 0.06 & 2-3 weeks \\
\hline & & 0.05 & & 1.00 & 0.05 & $0 \cdot 12$ & 2-3 weeks \\
\hline & & & & 1.00 & $0 \cdot 10$ & $0 \cdot 10$ & $>2$ months \\
\hline & & $0 \cdot 19$ & $0 \cdot 16$ & 1.00 & $0 \cdot 25$ & 3.94 & 2-3 weeks \\
\hline & & & & 1.00 & & $6 \cdot 40$ & 2-3 weeks \\
\hline & & 0.08 & & 1.00 & $0 \cdot 12$ & 3.02 & 3-4 weeks \\
\hline & & & & 1.00 & & $2 \cdot 52$ & 3-5 weeks \\
\hline
\end{tabular}

* Bacterial names that do not appear in the Approved Lists of Bacterial Names (Skerman et al., 1980), or subsequent validation lists published in the International Journal of Systematic Bacteriology, are written in inverted commas.

† Strain numbers of Laboratory for Culture Collection, Research Institute for Microbial Diseases, Osaka University; these strains were originally from Professor H. Saitō, Department of Microbiology, Shimane Medical School.

carbons with $\mathrm{C}_{24}$ predominating, a '24'-group' having 22 to 26 carbons with $\mathrm{C}_{24}$ predominating, and a '26-group' having 22 to 26 carbons with $\mathrm{C}_{26}$ predominating. The above groups seemed to relate partially to mycobacterial growth rate in vitro, since all species of the 22-group except $M$. leprae are rapid growers, requiring less than $3 \mathrm{~d}$ for colony formation, while all species of the 26and $24^{\prime}$-groups are slow growers, requiring 2-3 weeks or more for colony formation. No such relation could be observed for the 24-group.

\section{DISCUSSION}

Pyrolysis GC of mycolates has been of value in the characterization of different mycolatecontaining taxa such as mycobacteria, bacterionemas, corynebacteria, nocardiae and rhodococci (Lechevalier et al., 1971; Minnikin \& Goodfellow, 1980; Daffé et al., 1983). We 
found it hard, however, to distinguish small peaks of genuine fatty acid esters from contaminating ghost peaks in this technique; a combination of MS with pyrolysis GC, applied for the first time to mycobacterial mycolates, resolved these difficulties (cf. Fig. 1).

As shown in Table 1, the mycobacteria could be classified into four groups in respect of the pattern of the fatty acid esters released by pyrolysis of mycolates. The reproducibility of the apparent grouping of mycobacteria must be tested by analysing large numbers of strains. Our data from the pyrolysis GC of mycolates coincide completely with those of Daffé et al. (1983), who studied 27 species. It was unexpectedly found that our proposed grouping of mycobacteria seemed to have some relation to mycobacterial growth rate, though it is unclear why such a relation exists. In consideration of the known biosynthetic mechanism of mycolates (Shimakata et al., 1984) and the experiential relation between mycobacterial constitutive saturated fatty acid patterns and the length of mycolate $\alpha$-branches (Kusaka \& Izumi, 1983), mycolate $\alpha$ branches may be derived mainly from fatty acids formed by de novo fatty acid synthases in each bacterium. If so, there might be four types of mycobacterial fatty acid synthases or the associated thioesterases in respect of the product specificity.

We have reported previously (Kusaka et al., 1981) that the chain length of the $\alpha$-branch in $M$. leprae mycolates was 20 carbons; this must now be revised as mainly 20 carbons with lesser amounts of 22 carbons as shown in Table 1 . This result is in agreement with previous mass spectrometric studies on mycolates of $M$. leprae harvested from experimentally infected armadillos (Asselineau et al., 1981; Draper et al., 1982).

Our method described here has some value in helping to identify $M$. leprae. The pyrolysis GC of mycolates can be done within $2 \mathrm{~d}$ and requires less than $0.5 \mathrm{mg}$ dry weight of the unknown mycobacterial species. If mycolates from infected material produce, on pyrolysis, mainly 22 carbon, with lesser amounts of 24-carbon esters, it is probable that the infecting agent is $M$. leprae, especially if no rapid grower of the 22-group can be cultivated (Table 1).

This study received financial support from the US-Japan Cooperative Medical Science Program and Sasakawa Memorial Health Foundation, for which grateful acknowledgment is made.

\section{REFERENCES}

Asselineau, C., Clavel, S., Clément, F., Daffé, M., David, H., Lanéelle, M. A. \& Promé, J. C. (1981). Constituants lipidiques de Mycobacterium leprae isolé de tatou infecté expérimentalement. Annales de microbiologie 132A, 19-30.

Daffé, M., Lanéelle, M. A., Asselineau, C., LévyFrébault, V. \& DAVID, H. (1983). Intérêt taxonomique des acides gras des mycobactéries: proposition d'une méthode d'analyse. Annales de microbiologie 134B, 241-256.

DraPer, P., Dobson, G., Minnikin, D. E. \& MinniKIN, S. M. (1982). The mycolic acids of Mycobacterium leprae harvested from experimentally infected nine-banded armadillos. Annales de microbiologie 133B, 39-47.

ETÉmadi, A. H. (1967). The use of pyrolysis gas chromatography and mass spectroscopy in the study of the structure of mycolic acids. Journal of Gas Chromatography 5, 447-456.

KUSAKA, T. \& IZUMI, T. (1983). Gas chromatography of constitutive fatty acids in Mycobacterium leprae. Microbiology and Immunology 27, 409-414.

KusaKa, T., KoHSAKa, K., FuKunishi, Y. \& AKIMORI, N. (1981). Isolation and identification of mycolic acids in Mycobacterium leprae and Mycobacterium lepraemurium. International Journal of Leprosy 49 , 406-416.

Lechevalier, M. P., Horan, A. C. \& Lechevalier, H. (1971). Lipid composition in the classification of nocardiae and mycobacteria. Journal of Bacteriology 105, 313-318.

Minnikin, D. E. \& Goodfellow, M. (1980). Lipid composition in the classification and identification of acid-fast bacteria. In Microbiological Classification and Identification, pp. 189-256. Edited by $\mathbf{M}$. Goodfellow \& R. G. Board. London: Academic Press.

Minnikin, D. E., Dobson, G., Goodfellow, M., Draper, P. \& Magnusson, M. (1985). Quantitative comparison of the mycolic and fatty acid compositions of Mycobacterium leprae and Mycobacterium gordonae. Journal of General Microbiology 131, 20132021.

Shimakata, T., Iwaki, M. \& Kusaka, T. (1984). In vitro synthesis of mycolic acids by the fluffy layer fraction of Bacterionema matruchotii. Archives of Biochemistry and Biophysics 229, 329-339.

Skerman, V. B. D., McGowan, V. \& Sneath, P. H. A. (1980). Approved lists of bacterial names. International Journal of Systematic Bacteriology 30, 225-420. 